\title{
EVALUATION OF HOSPITALS WASTE MANAGEMENT PROCESS, THE CASE STUDY OF DUHOK CITY
}

\author{
QAidar N. AbDulsamad \\ Dept. of Spatial Planning, College of Spatial Planning, University of Duhok, Kurdistan Region-Iraq
}

(Received: September 21, 2020; Accepted for Publication: April 25, 2021)

\begin{abstract}
Duhok city, like other cities of the Kurdistan region, has witnessed a population growth that involved an increase in health-care demands, which has affected the waste generation amount from the existing health-care facilities including four hospitals. The objectives of this research are to explore the management of the hospital solid waste, investigate the approaches used for calculating it, and evaluate of its management process. Through this research, a sample of four public and private hospitals has been taken as case studies for investigating the hospitals' solid waste quantity and management.

The research findings estimated the solid waste generation rates of the four selected hospitals at 2,856 KG per month (Azadi Hospital - $841 \mathrm{Kg}$, Emergency hospital - $459 \mathrm{Kg}$, Vin Hospital - $636 \mathrm{Kg}$, and Vajin Hospital - $920 \mathrm{Kg}$ ).

Solid waste management is neglected in the private hospitals and inadequate management in the public hospitals in Duhok city because of the lack of regulation, policies, and instruction from the health and environment directorates of Duhok city.
\end{abstract}

KEYWORD: Hospital Waste, Generation Rates, Waste Handling, Waste Transportation, Treatment methods

\section{INTRODUCTION}

$\mathbf{P}$ opulation growth in a community is usually the result of economic and social development that further leads to an increase in the waste generated per inhabitant. Duhok city has seen rapid population growth in recent decades due to the development of the social and economic sectors. As a result, the municipal and hospital solid waste generated in the city has considerably increased. Therefore, inefficient or absence of waste management in the study area can lead to environmental pollution, unpleasant smell, and growth of insects, rodents, and worms, and potentially transmission of different diseases like typhoid and cholera through physical contact with the medical waste or through human blood which is contaminated from the syringes and medical equipment as supported by literature (Henry and Heinke, 1996)

Hospital waste management is the process of managing the waste of hospitals scientifically and is the primary way to control the hazardous waste, especially the waste of hospitals. This garbage can generate many types of hazards in the environment of the city. The management process in developing countries including Iraq is not safe, and they try to control the waste of the hospital. (Ali et al., 2017)

Hazardous waste is a waste that contains infectious materials that can threaten the public. The most dangerous waste in the world is the garbage generated by hospitals because the hospital waste can be contagious and can affect human life. (Blackman, 2016)

Healthcare facilities produce wastes with higher hazards of infection than municipal waste have. Therefore, special consideration and needs must be allocated for the requirement of healthcare waste management as a significance. Ethiopia is one of the developing countries which determine health-care waste management as a present issue. The rapid growth of the population in developing countries has become a reason for increasing the quantity of health-care waste in recent years, which consequently has led to an increase in the demand for the services of the health sector. The waste that is generated in public and private health-care facilities is disposed into the nature without being treated. (Tesfahun et al., 2014)

Many developed countries prefer to use restrictive regulations guidelines for health waste segregations, storing, and transportation. While developing countries had ineffective treatment 
regarding effective hospital waste management. (Patwary et al., 2011b). On average, highincome countries produce up to $0.5 \mathrm{~kg}$ of hazardous waste per day per hospital bed, while low-income countries produce an average of 0.2 $\mathrm{kg}$. In low-income nations, health care waste is not classified into hazardous or non-hazardous waste, making the actual volume of hazardous waste even higher (Health-care waste, 2018)

Many hospitals and health centers in Duhok city do not have proper medical hazardous waste (MHW) disposal and management. The medical waste is usually collected and transported to dumps or unregulated landfills outside the city without segregation from the municipal solids. In 2014, Duhok city produced 253.143 tons of hazardous medical waste. Currently, $30 \%$ of the medical waste generated there, i.e., directly disposed of in open dumps or landfills, is not sorted from municipal solid waste (Al-Ghabban et al., 2018)

The healthcare situation in Duhok city has not experienced an improved level, especially after the displacement of large number of people into this area. There has been a higher pressure on the existing hospitals and medical facilities. In Duhok city, there are 148 primary and specialized health centers, 9 public hospitals and 9 Private hospitals. In recent years, the growth and enhancement of the public and private health-care sectors in Duhok governorate have been regarded as the key factor in raising the production rate of hazardous waste (bio-medical waste) per capita in Duhok city (Al-Ghabban et al., 2018)

Salmaniya Medical Complex, which is one of the oldest and the largest hospital with capacity of approximately 882 beds, located in the Kingdom of Bahrain's Salmaniya district of Manama. Hazardous waste output ranges from
$0.038 \mathrm{~kg} /$ patient day (for a 10-bed small hospital) to $1.177 \mathrm{~kg} /$ patient day (for each large complex hospital with 882 beds). Evidence of the hospital waste generation rate It shows that $80 \%$ of hazardous hospital waste, produced by large public hospitals, where $74 \%$ produced by SMC. The data shows that the hospital waste generation was $1.28 \mathrm{~kg} / \mathrm{bed}$-day for inpatients at SMC and $0.17 \mathrm{~kg} /$ patient-day for outpatients. Internal health, pediatrics, obstetrics and gynecology, surgery and nephrology, primary procedures, have identified significant examples of hazardous waste generated for inpatient activities at SMC. In 2005, the findings studies about the country's amount of hospital waste confirmed that an approximate amount of 1.45 $\mathrm{kg}$ of hospital waste is produced by each person in the country. (Al-Thukair, 2009)

Healthcare waste is a hazardous type of waste that needs pretreatment solutions and cannot easily be reused and recycled. The items could be toxic, gene-toxic, radioactive, infectious, and some other types. Based on their form, segregating medical waste helps ensure that each waste is appropriately discarded, transported, and removed. These items harm the environment and human health as well. Hospitals waste increases with time pass because of population increase, and during recent years' hospital waste increased significantly (Arab et al., 2008)

\section{Background of the Case study}

Duhok city is the center of Duhok governorate; it is one of four major cities in the Kurdistan Region of Iraq. It is located between the Bekhair mountain at the north and northeast side of the city and Zawa mountain at the southeast side of the city (Figure 1). These two mountains make the expansion of the Duhok city to have a linear shape. 


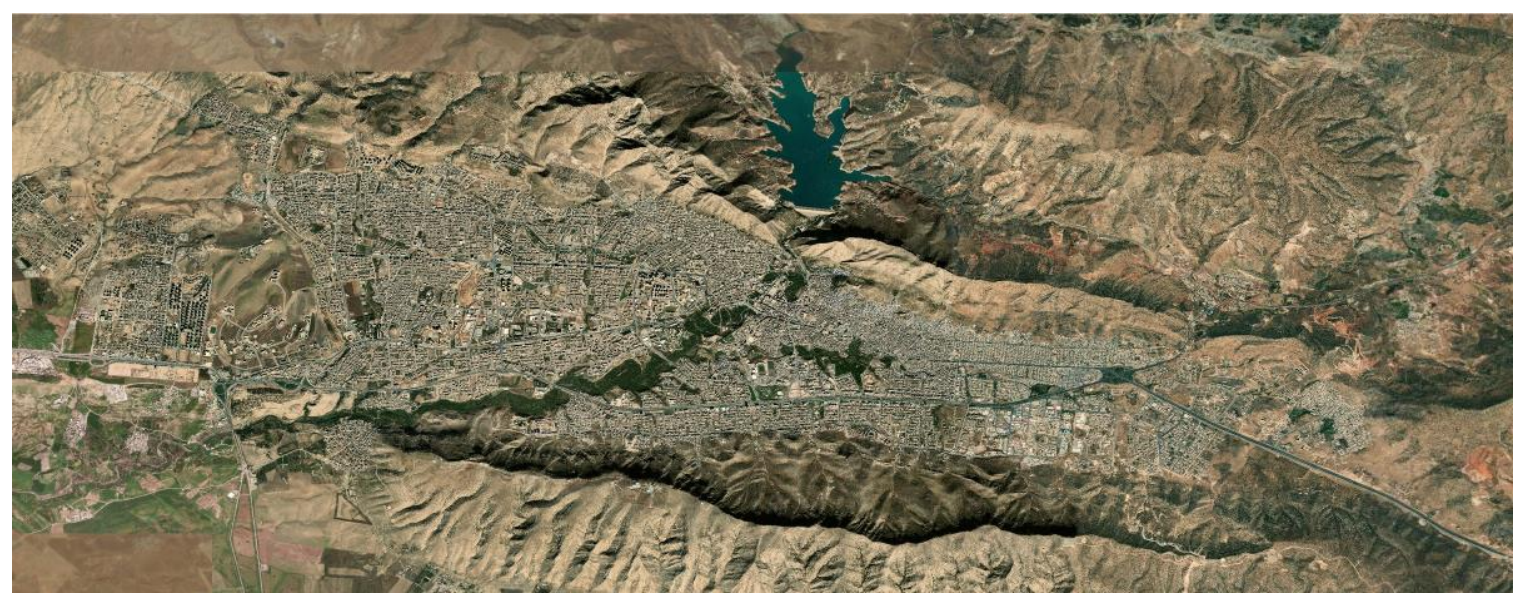

Fig.(1): Duhok city map, Source: from google map, 2020

Duhok city is about $10715 \mathrm{~km} 2$ and is a multicultural and multi-religion city with a population of approximately 350,000 persons. It was a small city in the past; due to political reasons, the Duhok city has expanded suddenly during the eighteenth century, which has increased the demand for health services. As a result, Azadi hospital was established in 1982. The city's rapid growth in the last decades has been accompanied by the increasing demand on health facilities. After 2005, private hospitals started to be implemented in Duhok city for the same reason; however, the demand was greater than the supply which led to the creation of investment opportunities in the private sector. The stable economic status of the individuals in Duhok city at that time was one of the reasons that led to establishment of private hospital develops in Duhok city.

\section{Problem statement and Aim of the study}

Duhok city faced an enormous population growth in recent decades due to rural-urban immigration, and large numbers of refugees and internally displaced persons (IDPs). The demand for hospital services has been increasing, which has a direct relationship with the amount of solid waste generation in hospital facilities. The absence of proper medical, solid waste management can affect inhabitants, especially when some of the hospital's solid waste mixes with the municipal solid waste that is generated by household and other sectors and delivered to Kwashe material recovery facility/sorting plant.
Where the manual separation of municipal solid waste is part of the sorting process at this facility, which means the workers/laborers are exposed to infectious diseases.

The aim of this study is to explore the quantity of public and private hospital solid waste generated and disposed into a landfill, as well as the available of treatment facilities and how it is collected, transported, treated, and disposed of.

\section{Methodology}

This study was carried out in Duhok city in 2020 to assess the management process of hospital solid waste of Duhok city. Field visits were made to four public and private hospitals; during which both qualitative and quantitative approaches were used through Interviews and observations. Thus, five interviews were conducted with different people with different positions (INDICATE POSITIONS). In addition, inspections and observation of collection and treatment facilities were made to triangulate data collected through the interviews.

For more accuracy, two public hospitals and two private hospitals were selected for interviewing, based on several factors such as hospitals operating a large number of surgeries amounting to 2500) per month, and hospitals include in the list of the top hospitals generating solid waste (Table 1) and hospitals specialized in treating a variety of diseases that lead to generating different types of hospital waste. 
Table (1): Statistics about surgical operations performed in Duhok city hospitals

\begin{tabular}{cccc}
\hline $\begin{array}{c}\text { Name of the public health } \\
\text { center }\end{array}$ & Number of surgeries & $\begin{array}{c}\text { Name of the private health } \\
\text { center }\end{array}$ & Number of surgeries \\
\hline Azadi hospital & 1000 & Vin hospital & 350 \\
\hline Emergency hospital & 900 & Vajin hospital & 250 \\
\hline Hivi hospital & 500 & Shelan hospital & 200 \\
\hline Gynecology hospital & 500 & Wan Global hospital & 170 \\
\hline Eye hospital & 250 & Duhok hospital & 160 \\
\hline hospital & 200 & Jeyan hospital & 150 \\
\hline
\end{tabular}

Source: Environment department of Duhok City, 2019

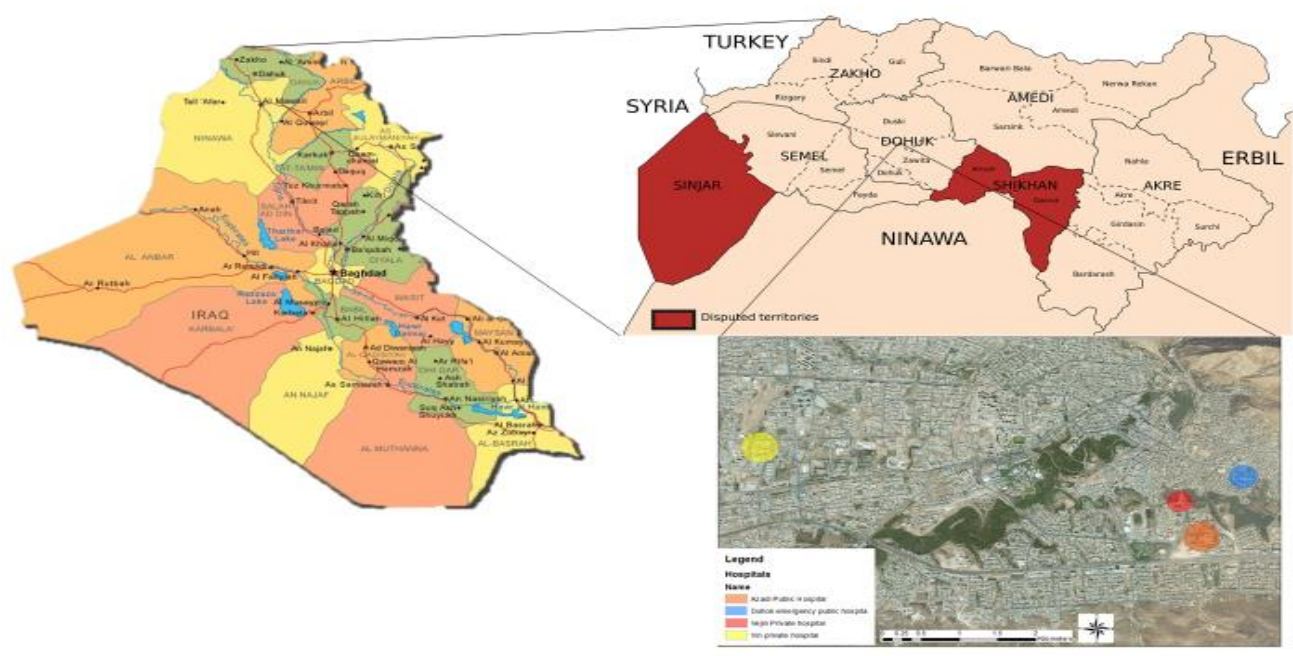

Fig. (2): Location of case study 


\section{Duhok Map - Hospitals}

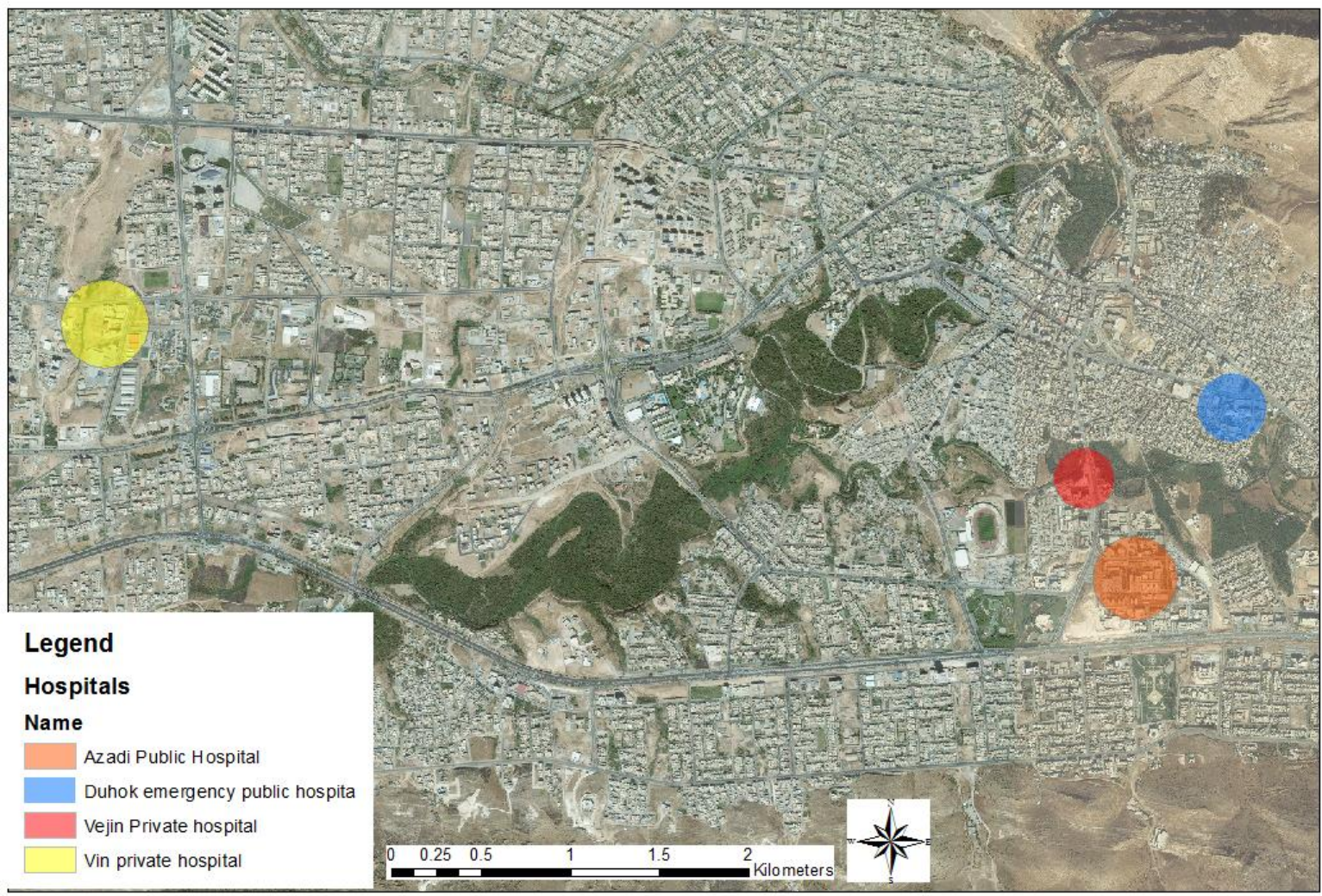

Fig. (3): Detailed map of selected case study areas

\section{RESULTS AND DISCUSSION}

The generation rate of Hospital solid waste in Duhok city Public hospitals

\section{Azadi hospital}

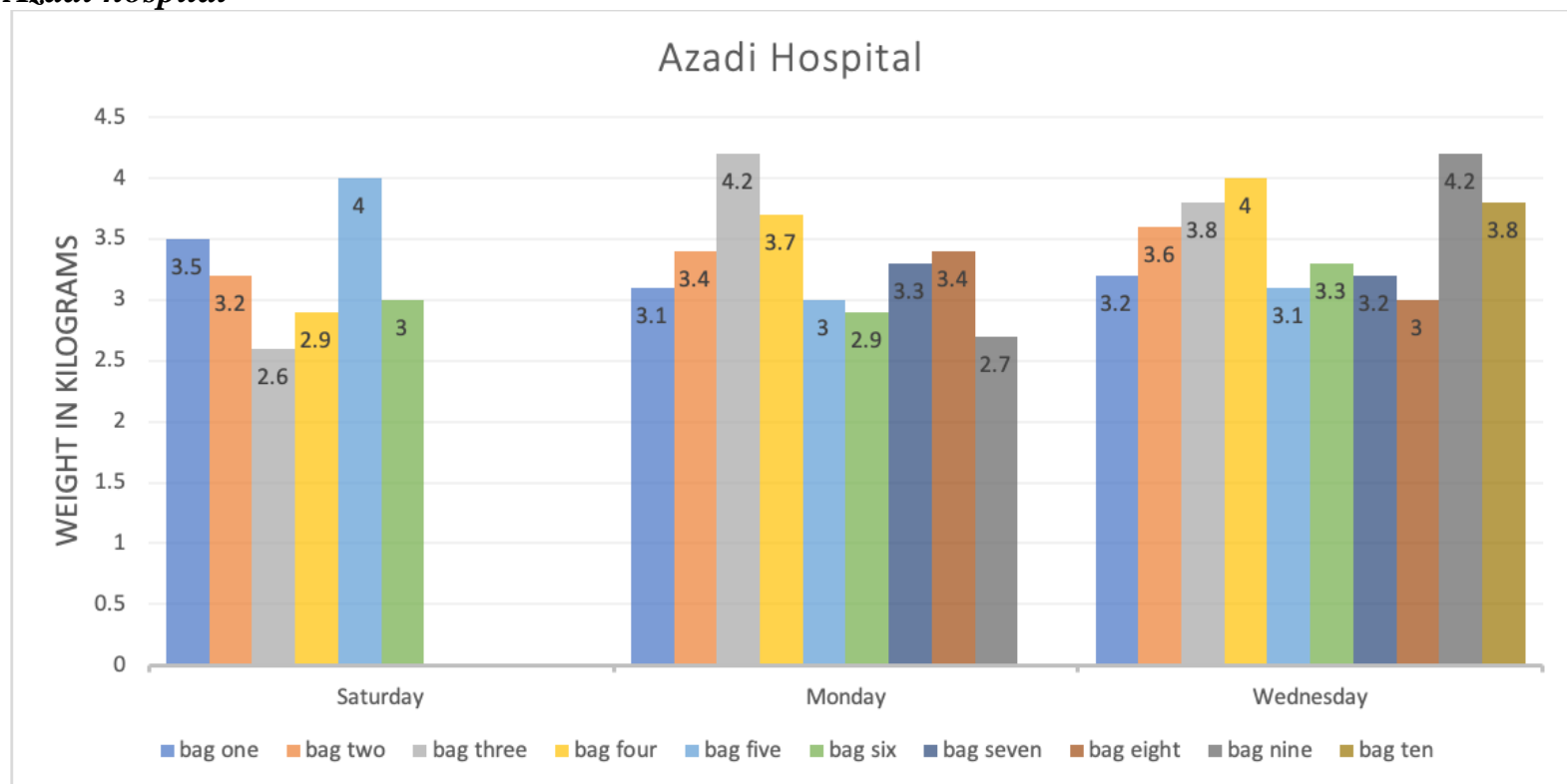

Fig. (4): Generation rate of hazardous waste in Azadi hospital 
The medical waste generated in the hospital varied across the three days. As Figures 4 and 5 display, $19.2 \mathrm{~kg}$ was generated on Saturday, 29.7 $\mathrm{kg}$ on Monday, and $35.2 \mathrm{~kg}$ on Wednesday. The main reason for the generation of less waste on Saturday is that the work in this day is part-time and most of the surgeries are done during other days of the week.

It can see that the highest quantity of waste was produced on Wednesday because of a high number of surgeries was conducted during this day, compared to other days.

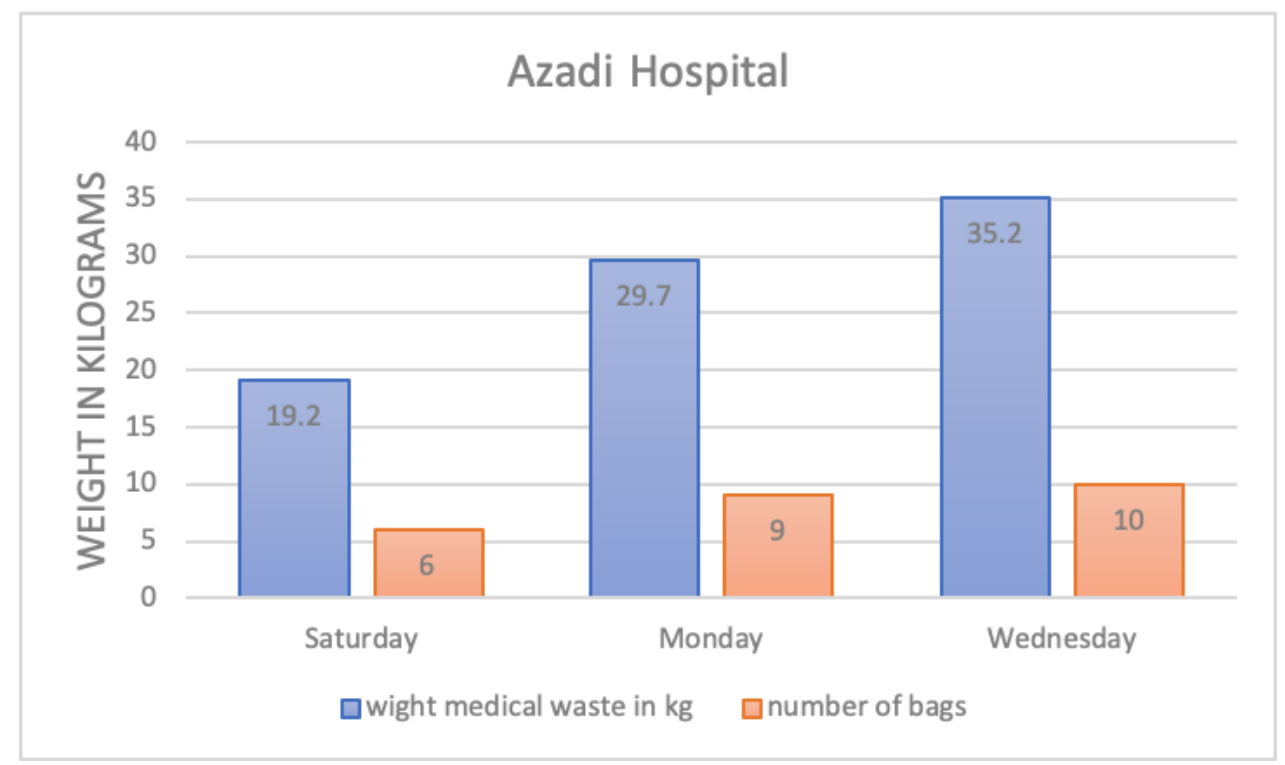

Fig. (5): Total amount of hazardous waste generated in Azadi hospital

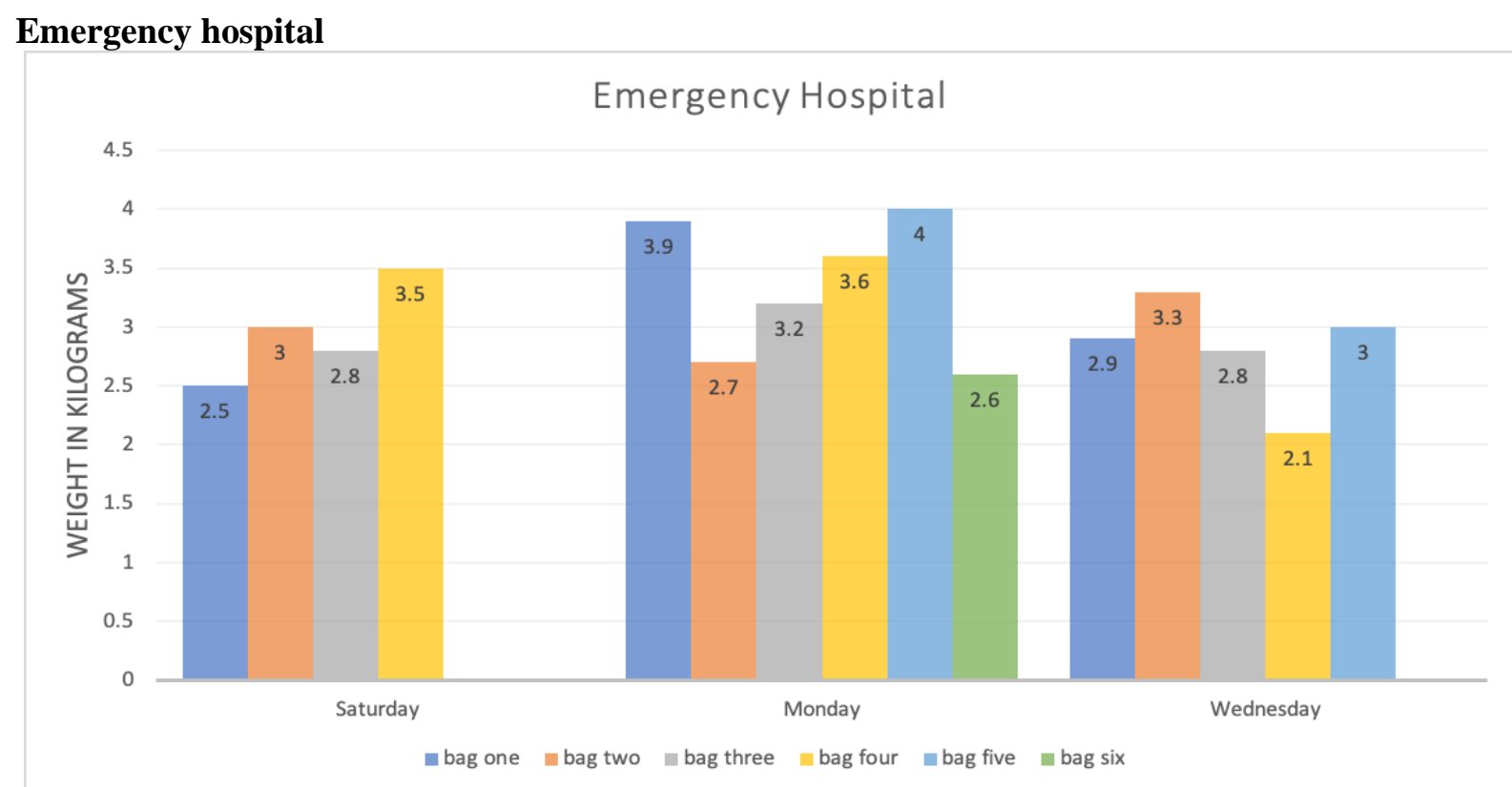

Fig. (6): Generation rate of hazardous waste in Emergency hospital

Likewise, less weight was generated in the Emergency hospital on Saturday $(11.8 \mathrm{~kg})$, compared to Monday $(20 \mathrm{~kg}$ ) and Wednesday $(14.1 \mathrm{~kg})$. (Figure 6) Despite considering the Emergency hospital at the top of the operator of surgeries, it generated less quantity of medical waste because of the surgeries done there are mostly primary surgeries with less amount of medical waste generated. In the (Figure7) determines the total amount of medical waste on different days of the week. 


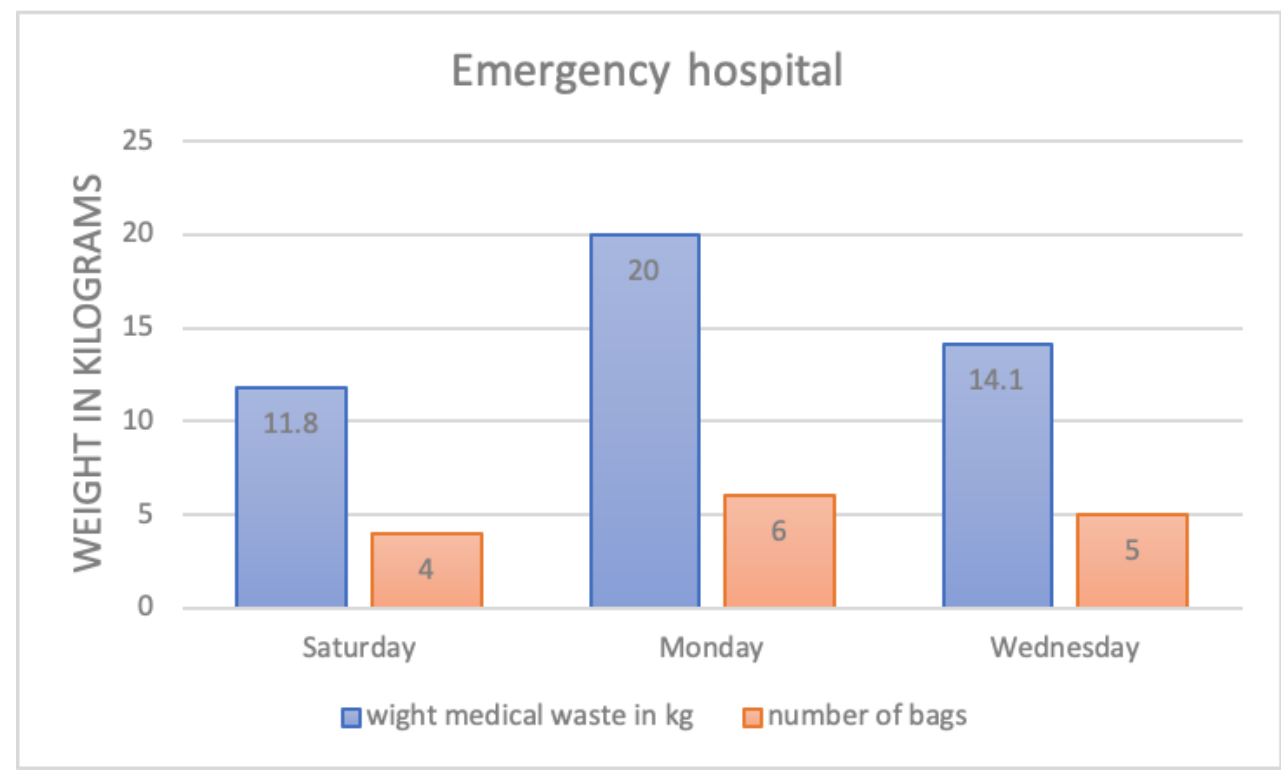

Fig. (7): Total amount of hazardous waste generated in the Emergency hospital

\section{Private hospitals \\ Vin hospital}

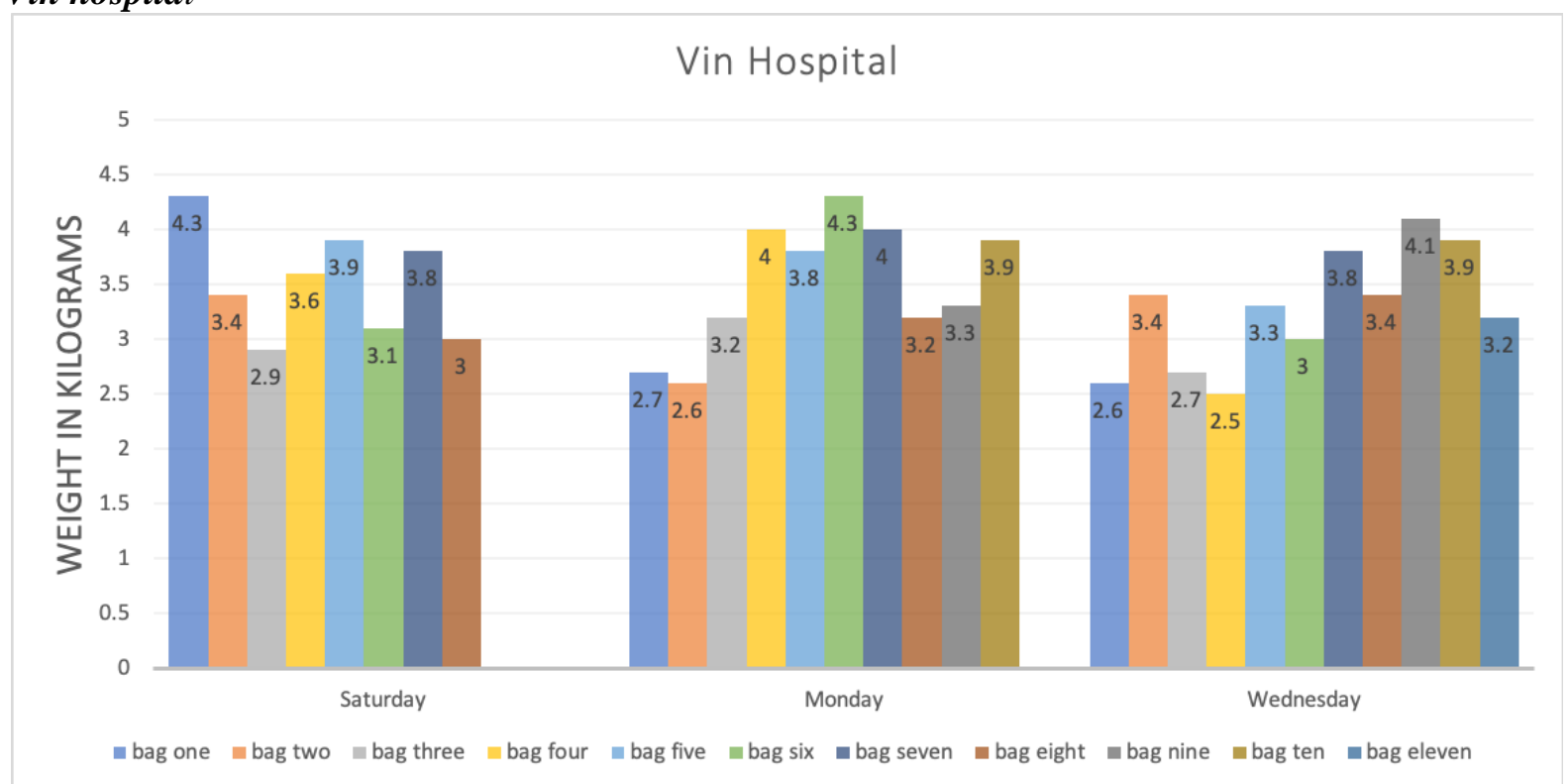

Fig. (8): Generation rate of hazardous waste in Vin hospital

In Vin hospital, a higher quantity of medical waste was observed (Figure 8). On Saturday, $28 \mathrm{~kg}$ of medical waste was measured, on Monday $35 \mathrm{~kg}$, and on Wednesday, $35.9 \mathrm{~kg}$. These high amounts of medical waste are the result of having non-medical waste collected in the waste bags without conducting any separation at the source. Thus, the amount of waste is greater than other public hospitals that separate the waste at the source (Figure 9). 


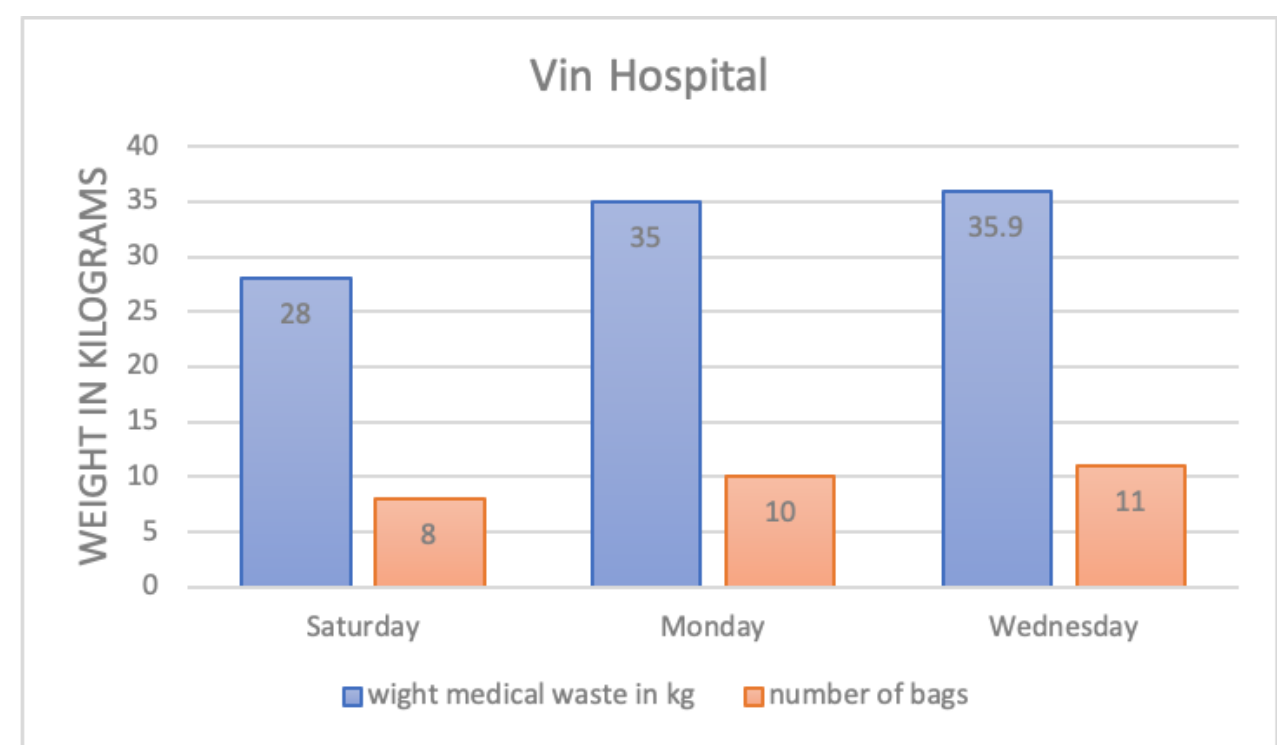

Fig. (9): Total amount of hazardous waste generated in Vin hospital

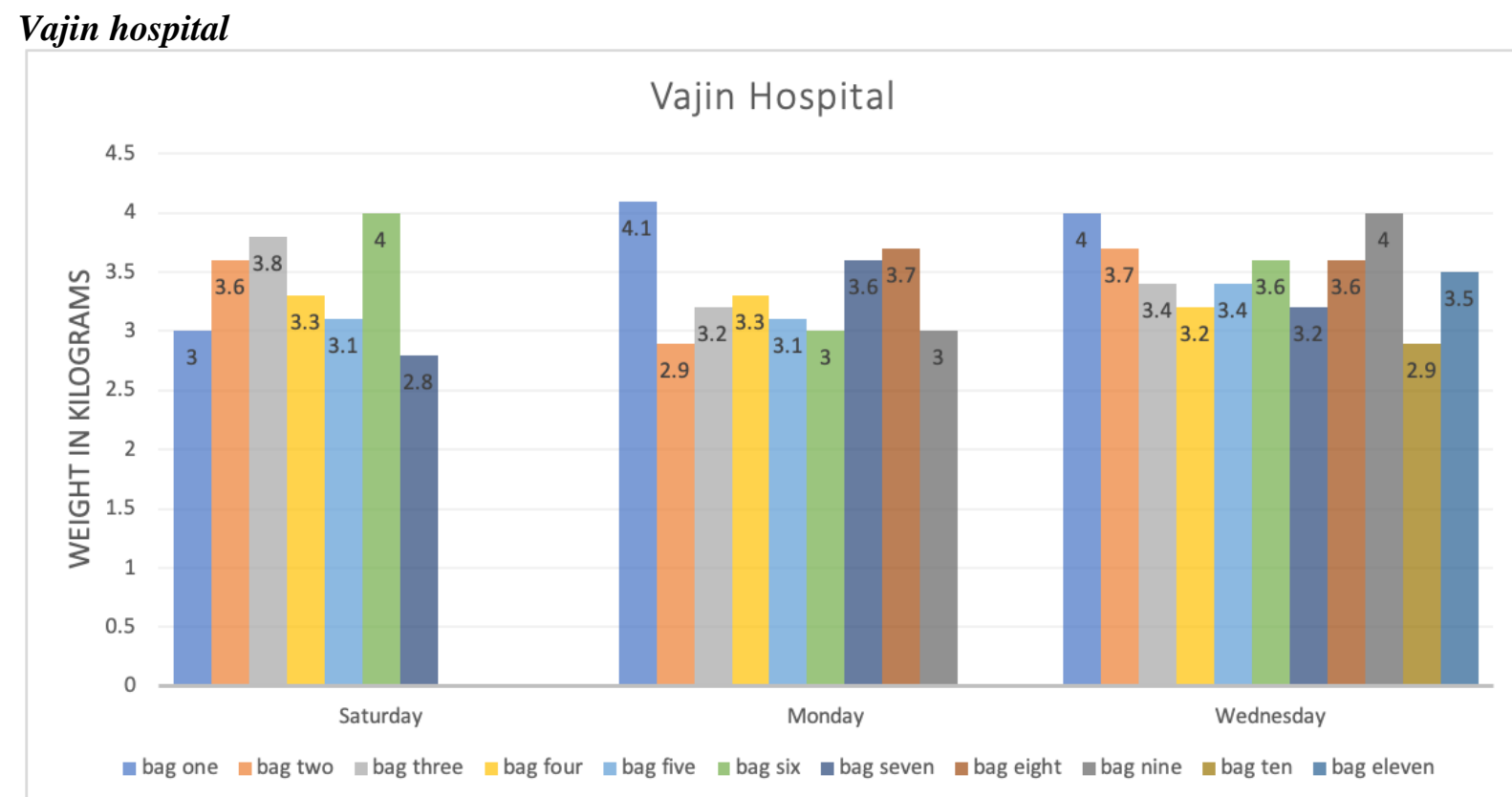

Fig. (10)2: Generation rate of hazardous waste generated in Vajin hospital

Vajin hospital also is one of the top producers of medical waste based on the number of surgeries that the hospital does. As Figure 10 shows, on Saturday, $23.6 \mathrm{~kg}$ of medical waste was produced while on Monday, 29.9kg. On
Wednesday, the highest amount of medical waste was recorded by measuring the bags of medical waste. A larger number of surgeries and health activities were conducted in this day. (Figure11) 


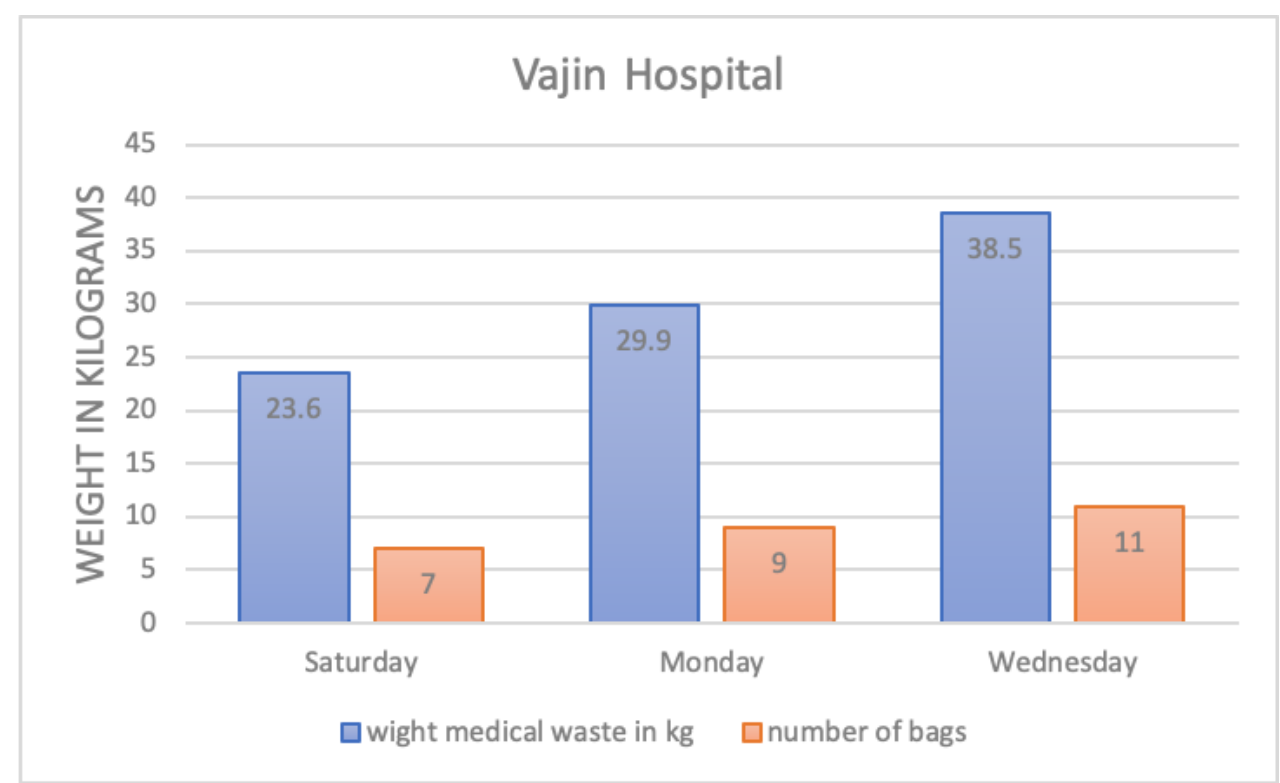

Fig. (11): Total amount of the hazardous waste generated in Vajin hospital

Comparatively, the public hospitals operate a greater number of surgeries than the private hospitals (Table 1), but the amounts of waste in the former hospitals are smaller than that in private hospitals (Figure

12).

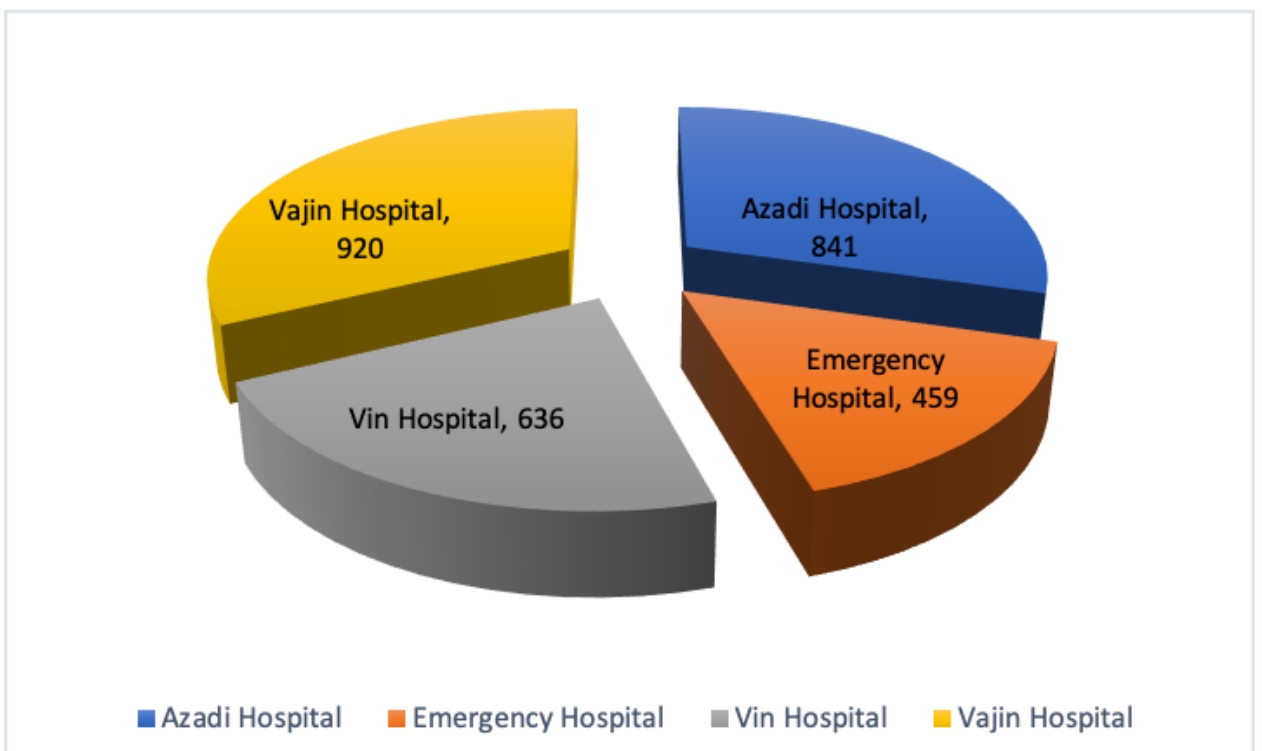

Fig. (12): Total amount (kg) of hazardous waste generated in selected case study hospitals

the hospital solid waste that is generated in health-care facilities is a mixture of hazardous and municipal waste, which illustrates that there is an absence of segregation process of waste in health-care facilities despite existing instructions from the Environment Protection Department. According to a study conducted by (environment department in Duhok city, 2019), the public hospital in Duhok city generates 25-30 tons of solid waste every month and the private hospitals generate 30 tons. The used material of medical products that each health-care facility use is the products that cannot be reused and are for one-time usage.

\section{Sorting of solid waste at the source}

Separation and identifying the type of hospital waste consider as a key to reduce and efficiently manage the medical waste (Safe management of wastes from health-care activities, 1999).

\section{Public hospitals}

Azadi hospital 
Azadi public hospital, to some, extent implemented a primary process of sorting as explored during the observation and interview (Figure 13). The black bags are used for municipal solid waste generated in the hospital, yellow bags for medical waste, red bags for blood and remains of human body that's generated from surgeries, and safety boxes for chemical and infected syringes.

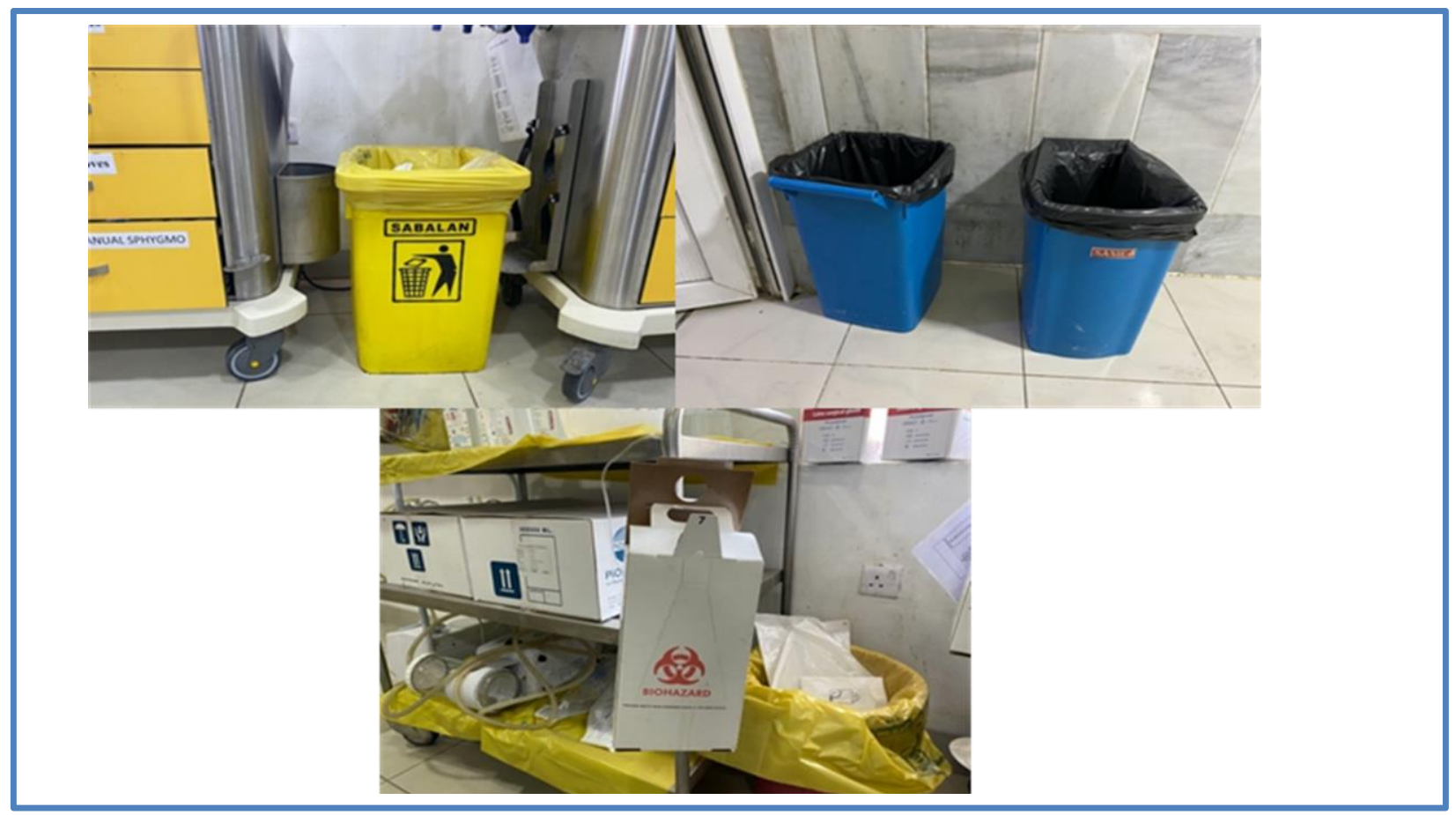

\section{Emergency hospital}

The emergency hospital of Duhok city operates the process of separation of waste for the waste that is being generated during emergency surgeries and other waste that is generated in their facility at the source point of producing.

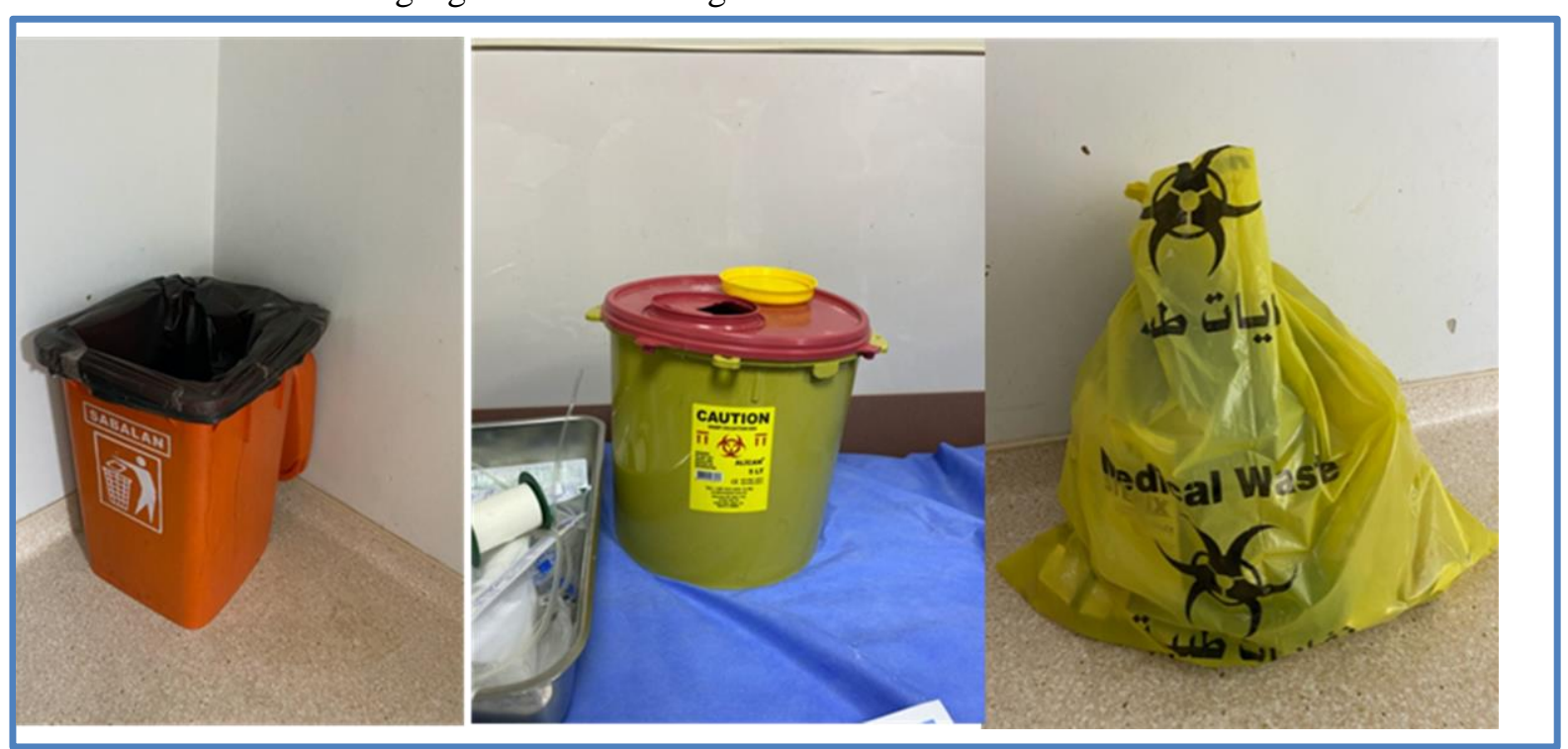

Fig. (14): Sorting of hospital solid waste in Emergency hospital

in this hospital, separation of waste is managed as follows black bags are used for the municipal waste, the yellow bags for infected material such as a cannula, fascia and ...etc. and carton safety boxes for infected syringes.

Private hospitals 


\section{Vin hospital}

There is no significant sorting waste process at source in Vin hospital. The waste generated in this facility is packed in one bag, which includes a mixture of both municipal and medical waste together except the syringes that are packed in safe plastic boxes and labeled as dangerous waste
(Figure
15).

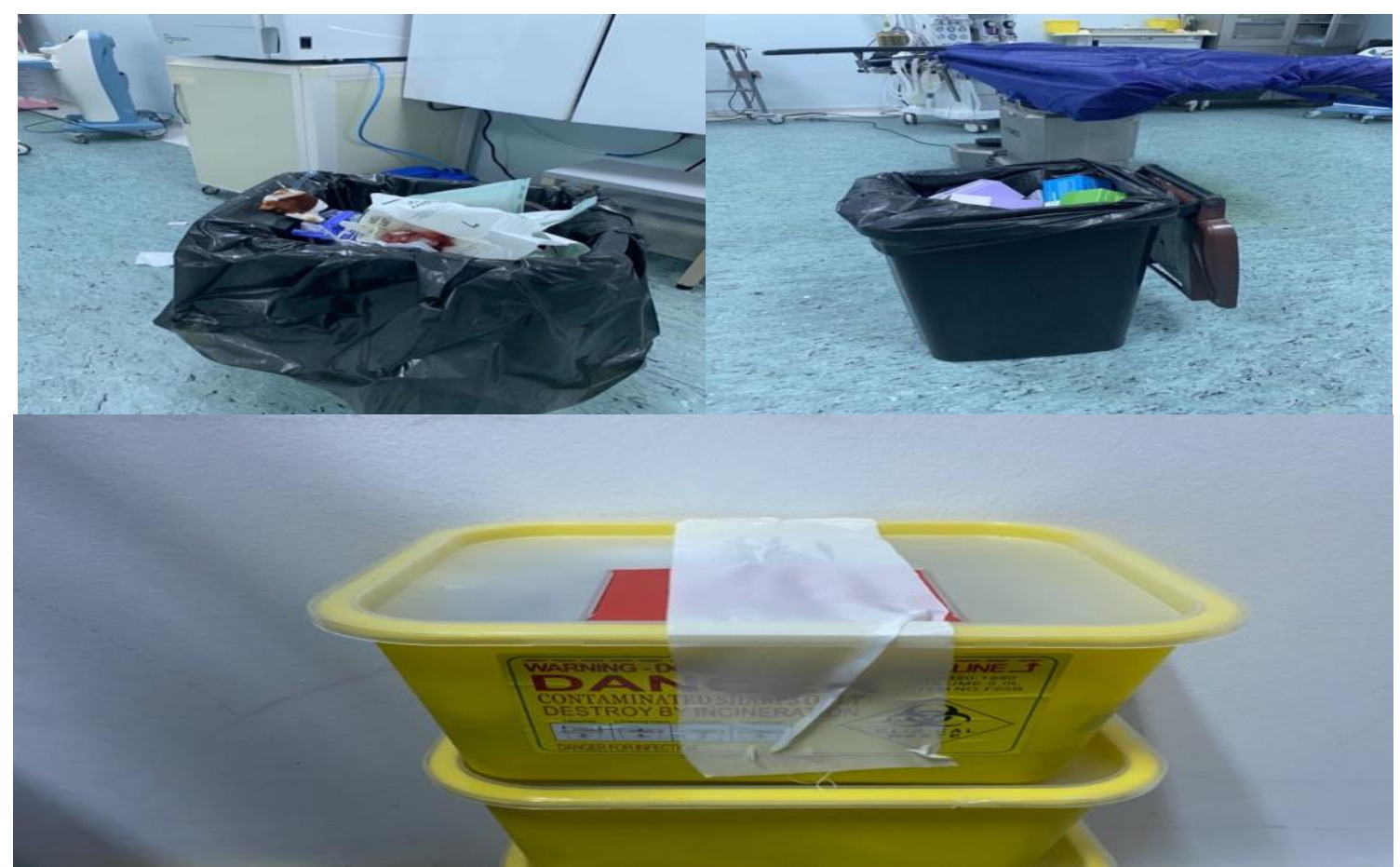

Fig. (15)3: Sorting of hospital solid waste in Vin hospital

\section{Vajin hospital}

The absence of a proper process of separation was noticed in Vajin hospital during the observation and interview with the manager of the Vajin hospital waste section. Medical waste generated from the surgeries and health activities are packed with other municipal waste that is not hazardous in one bag together except infected syringes, are placed on a safety boxes to keep away from the contact of the humans.

Lack of specific instructions and regulations in the department of environment of Duhok city regarding the classification of hospital solid waste led to absence of obligations from hospital facilities in case of separating and identifying the waste at the source of production in the facilities. Separation process of the medical waste is to some extent available in the public hospitals, while it is absent in the private hospitals. The findings illustrate that the waste in private hospitals is mixed, which makes the process more difficult and non-efficient.

\section{Handling of hospital solid waste}

Necessary procedure plans are necessary to ensure the safety of workers when collecting waste in health-care facilities. This waste can affect public health if it is not handled in safe temporary storage inaccessible to the people. Medical waste has the ability to pollute the air, which can cause diseases to inhabitants through direct or indirect contact via inhalation of waste emissions which consist of pathogens and chemicals. (SURNAME, 2019).

\section{Public hospitals Azadi hospital}


Handling process in Azadi hospital starts with manual collection of the medical waste at source by the workers on each floor on each day, and keeping it temporarily in an area to which patients and other people including visitors are vulnerable (Figure 16). This waste can

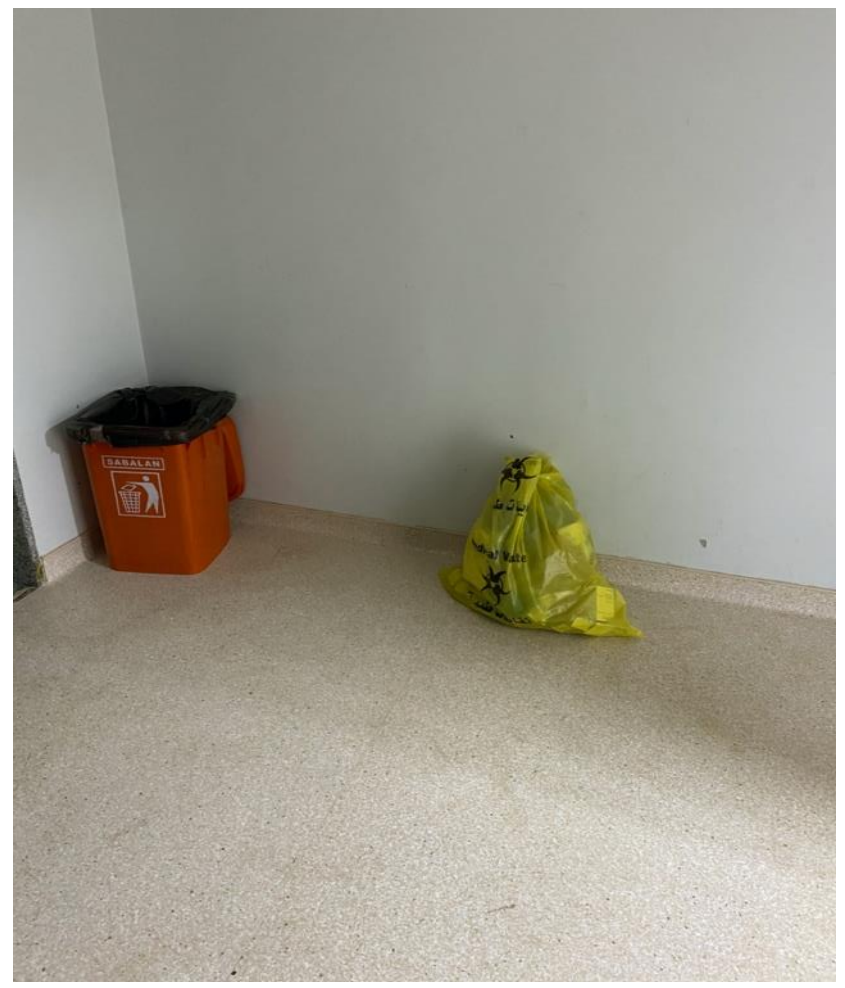

potentially contaminate other municipal waste

Fig. (16): Handling of hazardous waste in Azadi hospital

\section{Emergency hospital}

According to the Emergency hospital director, the medical waste is collected by the workers and kept in a place away and not accessible to other people for unknown reasons, the researcher was not allowed to observe and notice the condition of the place.

\section{Private hospitals}

\section{Vin hospital}

Handling of medical waste began after the waste is collected from every floor in the facility, two times a day. The collected waste is stored in a temporary safe place. This applies to the previous hospital which has been secured and made inaccessible to inhabitants except workers. The researcher was allowed to have access to the place in the condition of concerning individual safety. As shown on Figure 17, medical waste is stored all together in different bags in a container that alleviate the transportation of waste within the health facility. and infect people and workers with access to the place where it is kept because it is not secured. Any leakage from the medical waste bags could contaminate the place, which could ease the exposure of the inhabitants to these hazardous materials.

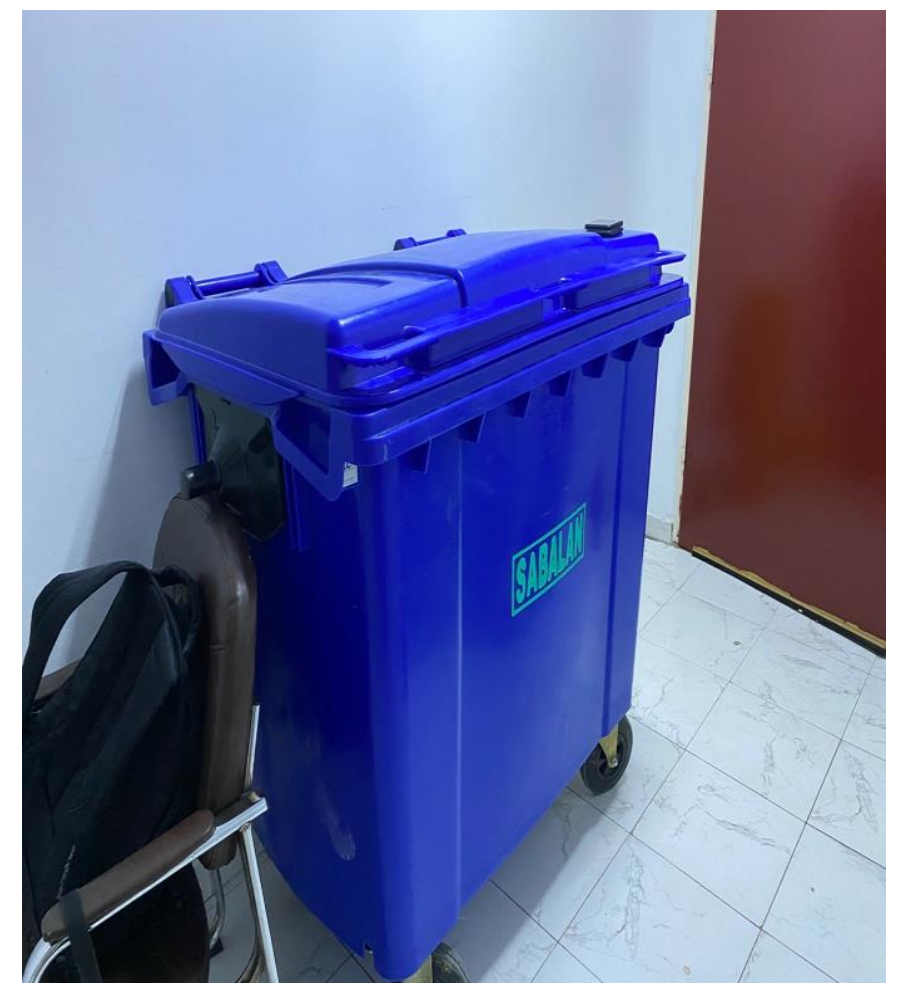

Fig. (17_: Handling of hazardous waste in Vin hospital

\section{Vajin hospital}

After waste generated at the Source is collected by the workers and stored in a place where it is segregated from the inhabitants that are not accessible for the others for the purpose of the safety of the public in case of any leakage or pollution that could infect the inhabitants. Despite self-safety measures taken by the researcher, he was not allowed to observe the location of the temporary storage.

\section{Transportation of hospital solid waste Public hospitals Azadi hospital}

Transportation of hospital waste in Azadi hospital is based on the type of waste; for instance, the municipal waste is transported by a city's municipal waste transport company. Other waste which is recorded as hazardous waste is treated inside the hospital which does not need special transportation trucks, as indicated by the manager of the waste section of Azadi hospital.

\section{Emergency hospital}


In the Emergency hospital, the municipal waste is transported by city's municipal waste transport company directly from the hospital. The hazardous waste that cannot be treated by the incineration of the hospital is transported by pickup truck to the landfill. It is to be noted that according to this waste should be transported by specialized trucks to protect public safety.

\section{Private hospitals \\ Vin hospital}

Transportation of hospital solid waste also depends on the type of waste. For municipal waste that is generated within the hospital is transported by the city's municipal waste transport company. As the hospital does not have a treatment plant, hazardous waste is transported by normal trucks to the Kwashe disposal place, which is open to the environment and public that can infect and pollute the public, as shown

in

Figure.18.
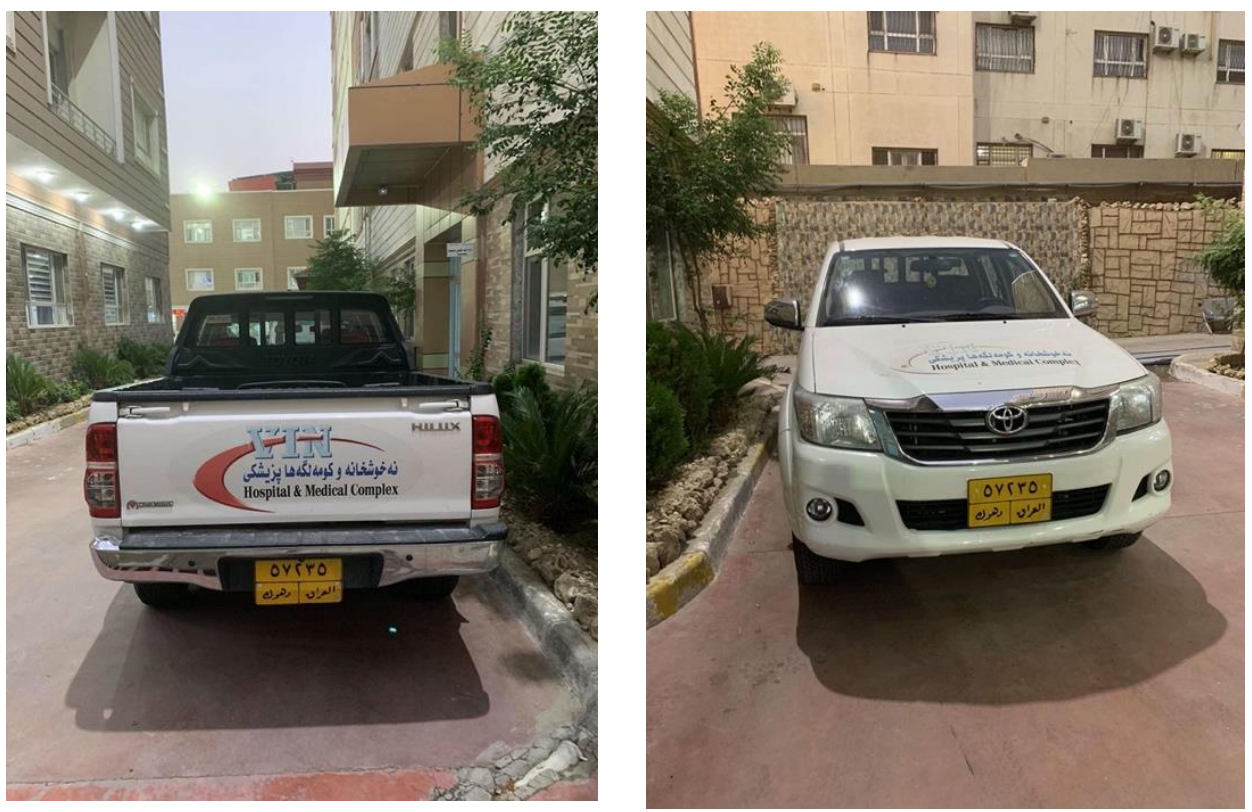

Fig. (18): Transportation vehicle of hazardous waste in Vin hospital

\section{Vajin hospital}

In Vajin hospital as well as other hospitals, the municipal waste is transported with city's municipal waste transport company (Figure19), and other hazardous waste that is generated in the hospital is transported by ordinary trucks to the other treatment plants in different hospitals.

This process is neglected by both the public and private hospitals as it is not taken into consideration by the responsible authorities.
Private hospitals transfer their waste using non special trucks to the Kwashe disposal place. This creates different risks including possible infection of the staff as well as contaminating the municipal waste which would require due treatment. The public hospitals do not have special trucks for transporting ash from the burned waste, which require special trucks for delivery to the landfill were it should be buried underground. 


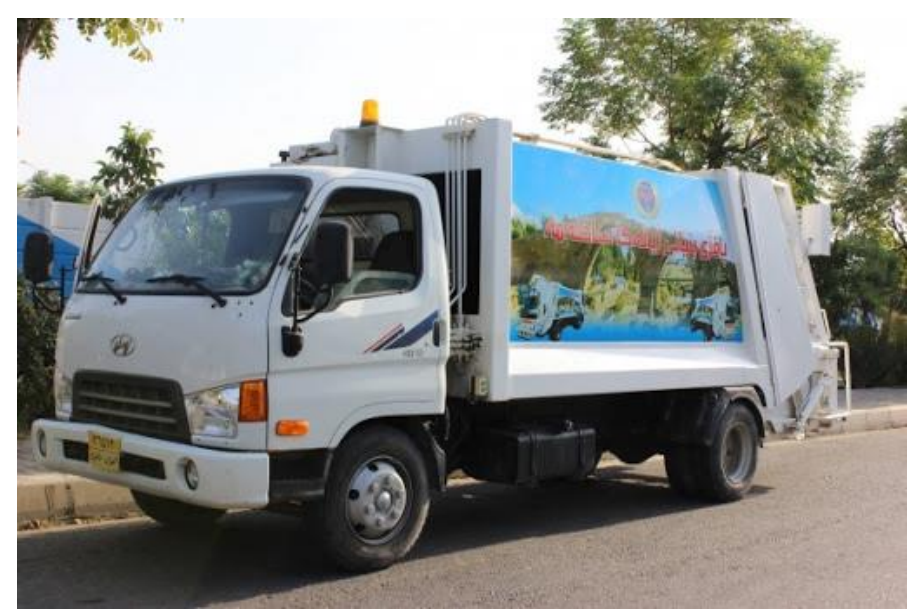

Fig. (19)4: Local company vehicle for transporting municipal waste from Vajin hospitals in Duhok city

\section{Treatment method of hospital solid waste}

The department of environment in Duhok city released instructions that require having autoclave and microwave treatment machines in every hospital as well as health-care facilities in order to disinfect and minimize the volume the most of the hospital waste that is produced.

\section{Public hospitals}

\section{Azadi hospital}

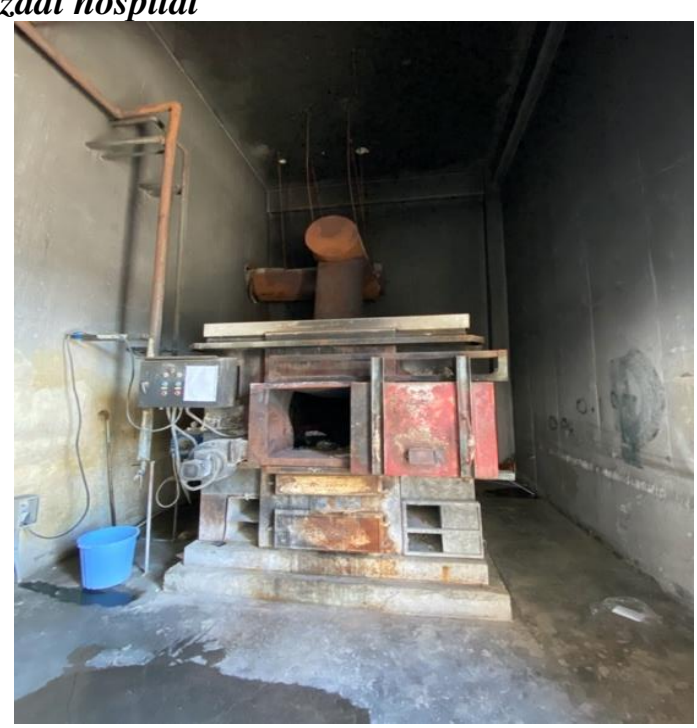

Fig. (20): Incineration treatment plant of Azadi hospital

According to the Azadi hospital manager, the incineration of Azadi hospital serves six hospitals and health centers in Duhok city because these facilities do not have treatment plants.

\section{Emergency hospital}

The available treatment methods in the emergency hospital are incineration and autoclave. The incineration burns the medical waste generated from the hospital facility. The autoclave is currently broken. The autoclave machine is not being fixed to disinfect the waste
Treatment methods that are available in the Azadi hospital are outdated and ordinary incineration treatment plant for treating the hazardous medical waste inside of this facility. That burns the medical waste with a single chamber fire, as shown in the Figure.20.

Currently, the incineration treatment plant is not working correctly due to the lack of initial maintenance and technician staff.

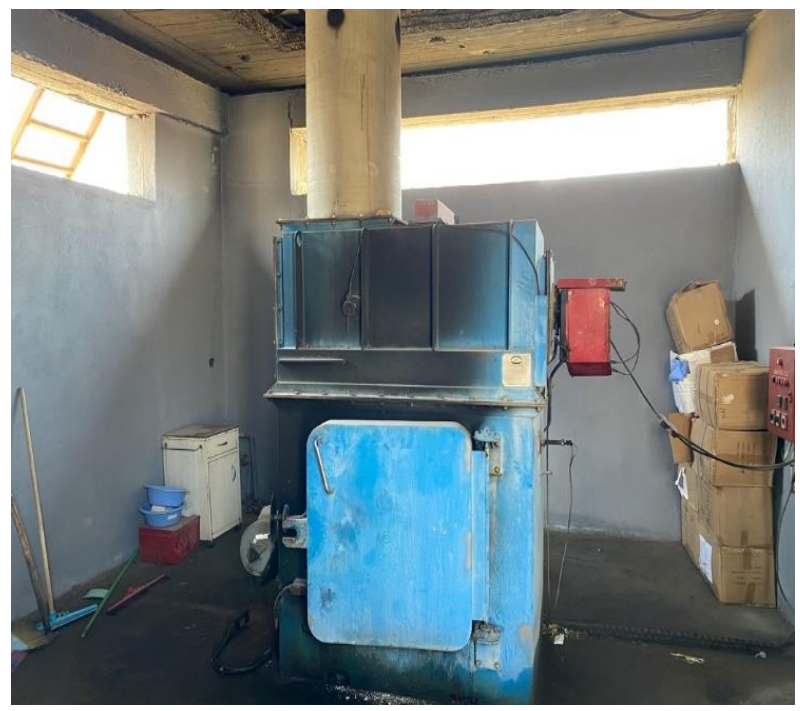

Fig. (21): Incineration treatment plant of Emergency hospital

and minimize hazardous waste (Figure 21). The incineration facility for emergency hospital has two chambers; the first chamber is used for burning the medical waste while the second chamber for burning the smoke, which is produced from burning the medical waste that contains many hazardous substances. As a result, the emissions of this incineration do not include of any hazardous substances.

The hospital has a cargo with an amount of expired medicine that cannot be treated with incineration because of the high toxicity of the 
medicines; thus, it is stored in a place (Figure 22), and then been buried underground in Kwashe landfill.
According to the manager of the incineration, each day, 25 kilograms of medical waste are burnt while the municipal waste is dumped into landfill in the Kwashe treatment plant.

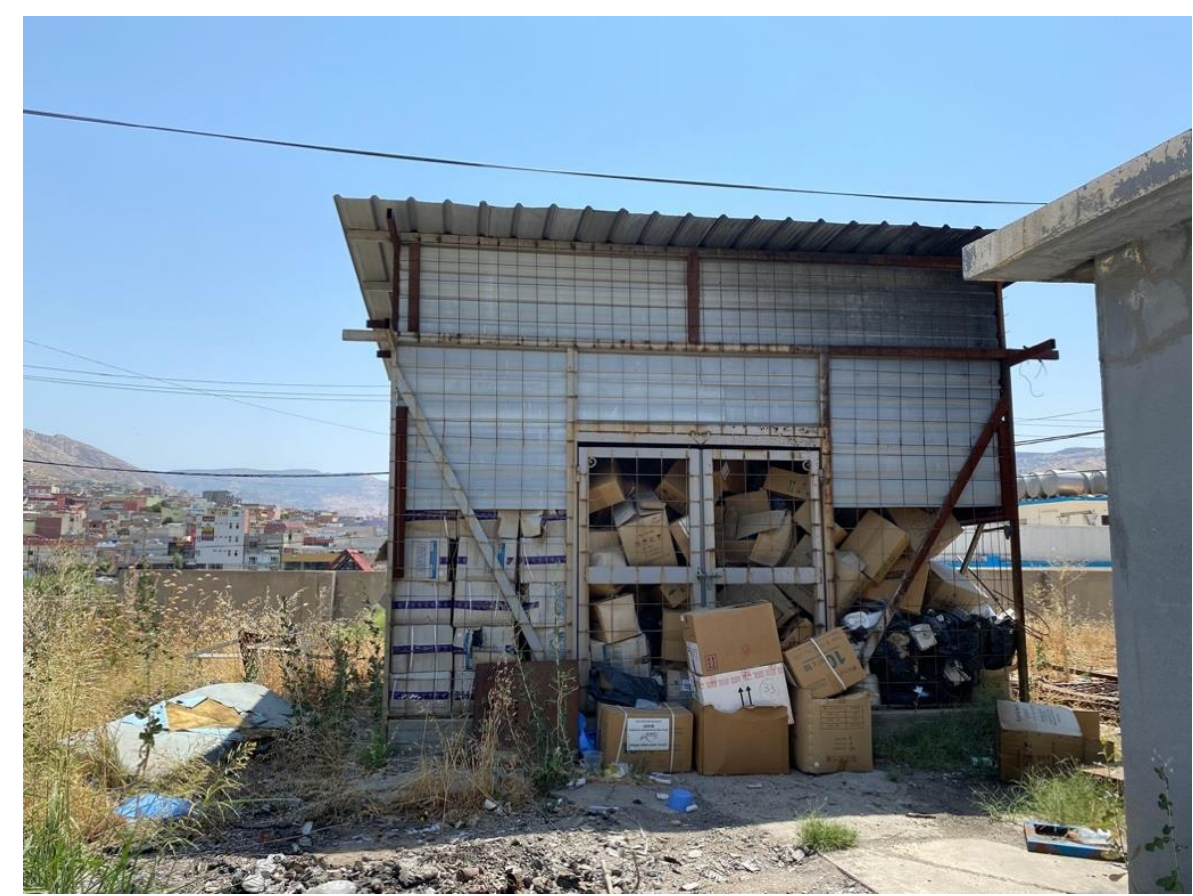

Fig. (22): Temporary storage for hazardous waste that need special treatment in Kwashe landfill

\section{Private hospitals}

\section{Vin hospital}

No treatment plant method has been noticed in Vin hospital as the waste is treated in other hospital facilities. Despite having the regulations and instruction from the environment department in Duhok city that insists on having the autoclave and microwave machines inside the hospital facilities, the waste $\mathrm{t}$ generated in Vin hospital is disposed of in the treatment plant of Kurdistan maternity hospital which is located close to it.

\section{Vajin hospital}

In Vajin hospital, no treatment methods are used for treating the hazardous waste of the hospital despite having the instruction from the Environment protection department as indicated above. The hazardous waste from the Vajin hospital is transported to other treatment plants in Azadi public hospitals.

\section{CONCLUSION}

In conclusion, this research was conducted to measure and determine the generation rate, management, and available facilities to treat hospital solid waste of Duhok city. In total, four hospitals ( 2 publics and 2 private) were selected as case studies. The generation rates of the four hospitals were approximately 2,856 KG per month (Azadi hospital $841 \mathrm{Kg}$, Emergency hospital $459 \mathrm{Kg}$, Vin hospital $636 \mathrm{Kg}$, and Vajin hospital $920 \mathrm{Kg}$ ). The main sources of hazardous waste are surgeries made in the hospitals, expired medicines, and infected materials used during the surgeries.

Management of the generated hazardous waste is not done properly due to the inadequate classification of waste at the Source of production. In public hospitals, the classification process is applied, and the waste is separated and identified based on their type. In contrast, in 
private hospitals, the classification of waste is not used, and all kinds of waste are mixed when collected.

The handling of waste from the source of production was different from one hospital to another; for instance, in Azadi hospital, the waste was collected and stored temporarily where other people except workers have access to the site. Unlike wise, the Vin private hospital, the waste is kept in a place where only the workers have access to that place, which can be a reason to spread diseases to inhabitants.

In terms of transportation of waste, the municipal waste is being transported by the city's municipal waste transport company to the Kwashe landfill in all health-care facilities. Although transportation of hazardous waste depends on the availability of treatment facility inside the hospitals. However, public hospitals have treatment facilities; thus, the hazardous waste only requires a wheeled container to be transported to the treatment plant. As private hospitals do not have treatment plants/facility, the waste is transported by normal pickups that are not secured for the protection of public health and the environment.

In regards of the facilities for treating the hazardous waste that is generated from the four hospitals, the Environment department of Duhok city has released certain instructions about having treatment plants inside of hospital facilities (see Appendix 1), as well as insisting that each hospital facility should have an autoclave and microwave shredders in case of disinfecting the hazardous waste. Late release of instructions from the environment department of Duhok city, lack of area required for constructing treatment plant, and the high costs of the treatment plants are the causes that have made the private hospitals to not have waste treatment plants. Whereas public hospitals are provided with the treatment plants as they do not have issues like land or cost.

\section{REFERENCES}

Al-Ghabban, M. M., Mizzouri, N. S., Mahmood, F. R., Hassan, H. H., \& Abdulrahman, K. I. (2018). Assessment of Waste Generation rate of Medical Hazardous in Duhok Governorate (Proposal of alternative disposal and management methods). Academic Journal of Nawroz University, 7(4), 139-152. doi:10.25007/ajnu. v7n4a283

Ali, M., Wang, W., \& Chaudhry, N. (2016). Application of life cycle assessment for hospital solid waste management: A case study. Journal of the Air \& Waste Management Association, 66(10), 1012-1018. https://doi.org/10.1080/10962247.2016.11962 63

Ali, M., Wang, W., Chaudhry, N., \& Geng, Y. (2017). Hospital waste management in developing countries: A mini review. Waste Management \& Research, 35(6), 581-592. doi: 10.1177/0734242X17691344

Arab, M., Rouhollah Askari, B., Tajvar, M., Pourreza, (2008). Report: The assessment of hospital waste management: a case study in Tehran. Waste Management \& Research, 26(3), 304-308.

DOI: $10.1177 / 0734242 X 08093598$

Al-Thukair, A., Mohamed, L. F., \& Ebrahim, S. A. (2009, April 19). Hazardous healthcare waste management in the Kingdom of Bahrain. International Journal of Integrated Waste Management, Science and Technology, 29 (2009), 2404-2409. doi: 10.1016/j.wasman.2009.02.015

Blackman, W.C. (2016). Basic hazardous waste management. CRC press

Buy OptiMaser- Microwave Medical Waste Disinfection \& Sterilization System | ID 1612215. (2020). Retrieved 9 April 2020,fromhttps://www.exportersindia.com/ss medicalsystems/optimaser-microwavemedical-waste-disinfection-sterilizationsystem-lucknow-india-1612215.htm

Caros, (2018, June 12). What Is Biomedical Waste: Medical Waste Examples: MedWaste Services. Retrieved March 23, 2020, from 
https://medwasteservice.com/biomedical-

waste-examples/

Debere, M.K., Gelaye,K.A., Alamdo, A.G., \&Trifa, Z.M. (2013). Assessment of the health care waste generation rates and its management system in hospitals of Addis Ababa, Ethiopia. BMC Public Health,28(2013), 13-28. https://doi.org/10.1186/1471-2458-13-28

Gambo, J., Ahmed, G., Hadiza, Z. H., Idris, M.A., Babura, B.S. and Yusuf A.Y, (2018). Assessing the Impacts of Improper Medical Waste Disposal and Residents Perception of their Disposal Practices in Hadejia Metropolis, Jigawa State, Nigeria. Nigerian Research Journal of Chemical Science, 4(2018).

Henry, J., and Heinke, G. (1996). Environmental science and engineering. Brooklyn Park, MN: Pearson

Marceta, M., \& Nađ, I. (2018). Effect of medical waste on health of population and environment in the Republic of Serbia. Zbornik Radova Departmana Za Geografiju, Turizam I Hotelijerstvo, (47-2), 94-112. doi: $10.5937 /$ zbdght $1802094 \mathrm{~m}$

Medical Waste Treatment Methods. (2020, October 24). Retrieved 11 March 2020, from https://www.hazardouswasteexperts.com/regul ated-medical-waste-treatment-methods/.

Medical Waste Treatment Solutions for Contaminated Biohazardous

Waste.
Medicalwasteautoclaves.com.

(2020).

Retrieved 11 April 2020, from https://medicalwasteautoclaves.com/medicalwaste-treatment.php.

Mehrdad Askarian, Mahmood Vakili \& Gholamhosein Kabir. (2004). Results of a hospital waste survey in private hospitals in Fars province, Iran. Waste Management, 24(4), 347-352.

doi: 10.1016/j.wasman.2003.09.008

Mumtaz Hussain, M. M. M. (2014). Awareness about Hospital Wastes and its effects on the Health of Patients in District Dera Ghazi Khan Mumtaz, Asian J. Appl. Sci. Eng., 3 (8), 111115 .

Prüss A, Townend WK, Teacher's guide: safe management of wastes from health-care activities; unpublished document WHO/EOS/98.6.

Tesfahun, E., Kumie, A., Legesse, W., Kloos, H., \& Beyene, A. (2014). Assessment of composition and generation rate of health-care wastes in selected public and private hospitals of Ethiopia. Waste Management \& Research, 32(3), 215-220. doi: $10.1177 / 0734242 \mathrm{X} 14521683$

WHO (World Health Organization) (2004). Safe health-care waste management. Policy paper. No. 27. Geneva: World Health organization.

WHO (World Health Organization) (2018). WHO fact sheet. http: / / www.healthcarewaste.org. 
Appendix 1: Instructions regarding the treatment facilities in the hospitals by Environmental Protection and Improvement Board of Ministry Council of KRI-Iraq

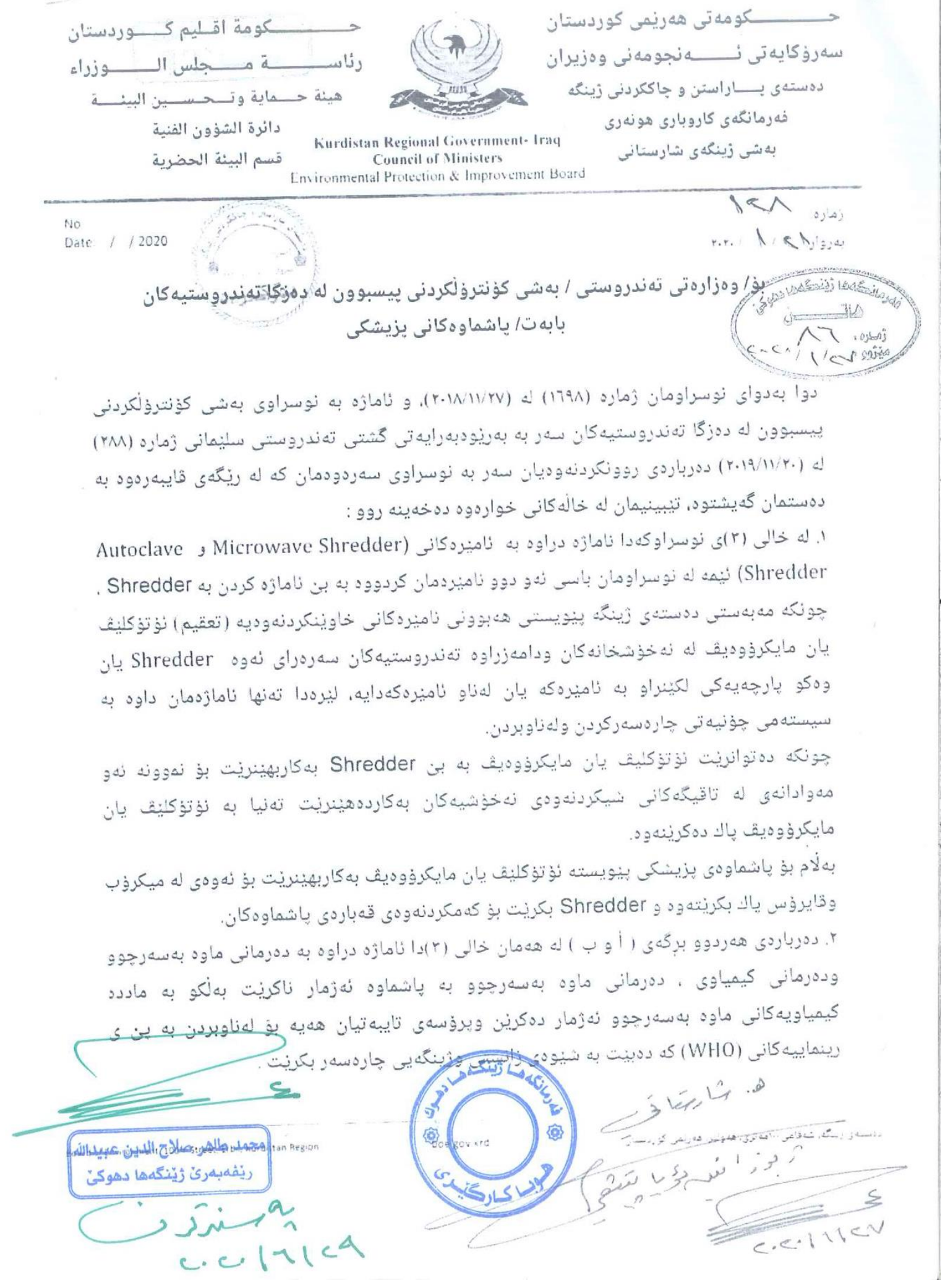




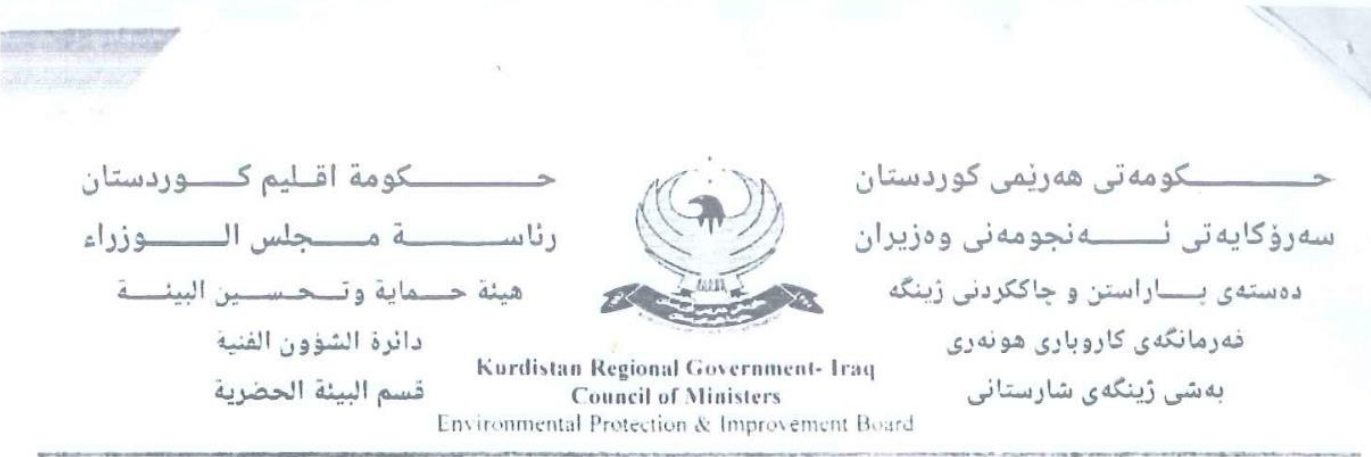

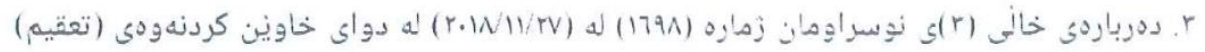

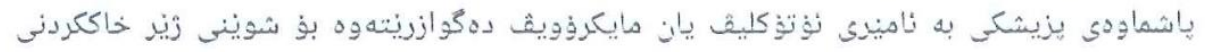

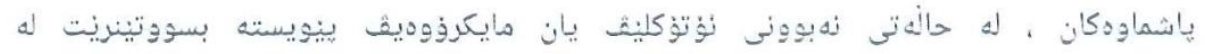

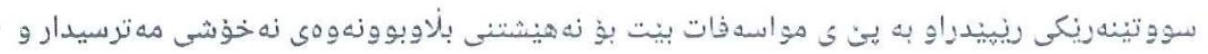

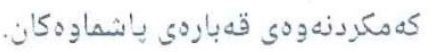

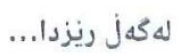

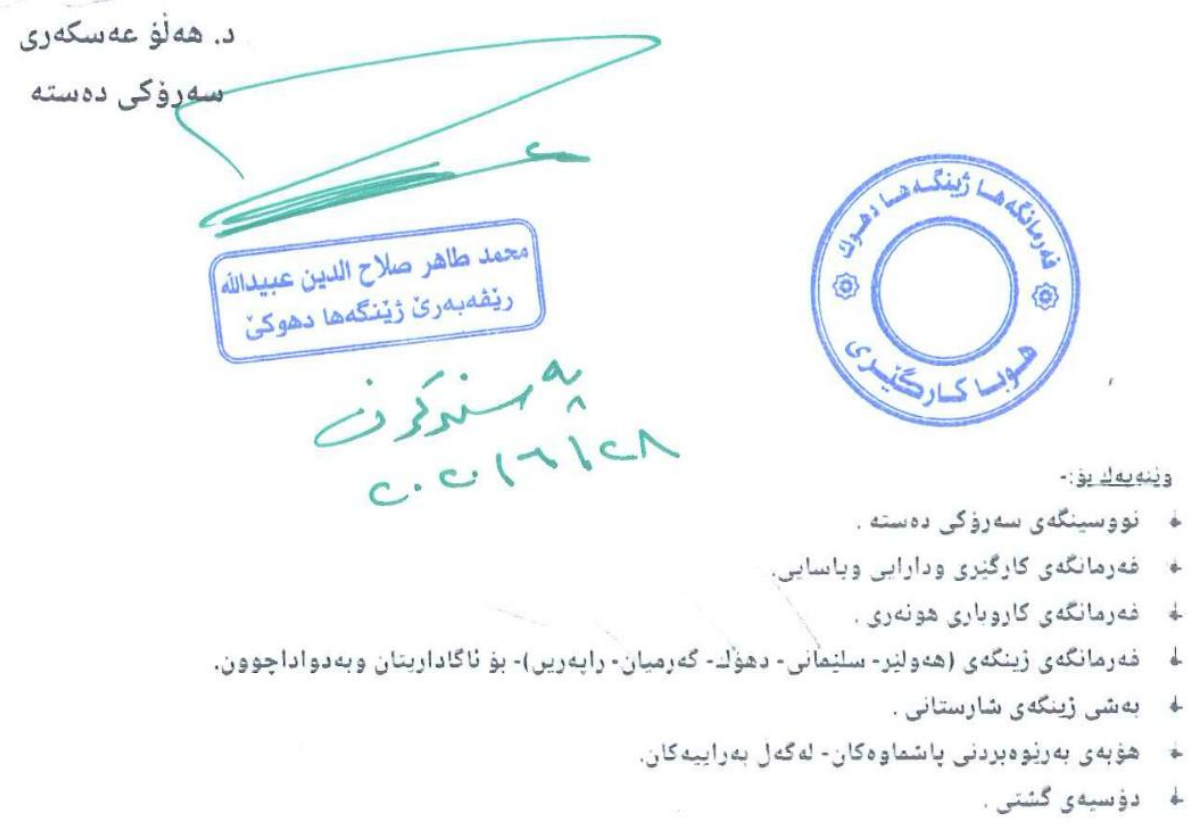

